\title{
Values of plasma lipid hydroperoxides and total antioxidant status in healthy dairy cows: preliminary observations
}

\begin{abstract}
Metabolic parameters have been used in an attempt to monitor the health, reproductive and nutritional status of dairy cows. Nevertheless, in the last few years the detection of free radical damage, and the protection against it has become very important in the practice of clinical medicine. This report aims to establish values for plasma lipid hydroperoxides (LOOH) and total antioxidant status (TAS) in healthy cows and its relationship with milk yield. The study was carried out with 22 healthy dairy cows divided into two groups: animals with a low production rate and animals with a high milk yield. Results showed that the animals with a high milk yield present higher $\mathrm{LOOH}$ levels than the other group. This increase in oxidant compounds is not accompanied by higher levels in protective antioxidant substances. LOOH and TAS measurements give complementary information about the metabolic status of the animal than metabolic parameters alone.
\end{abstract}

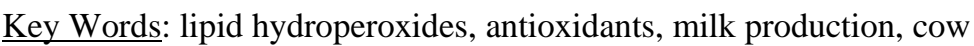

\section{Zusammenfassung}

Titel der Arbeit: Plasmalipidhydroperoxidwerte und Gesamtantioxidansstatus bei gesunden Milchkühen: Erste Beobachtungen

Bisher hat man versucht, mit metabolischen Parametern den Gesundheits- und Reproduktionsstatus sowie den Ernährungszustand von Milchkühe zu bestimmen. In den letzten Jahren gewann jedoch die Bestimmung der durch freie Radikale verursachten Schäden sowie der Schutz vor diesen eine große Bedeutung in der klinischen Medizin. Dieser Beitrag hat das Ziel, die Plasmalipidhydroperoxidwerte (LOOH) und den Gesamtantioxidansstatus (TAS) bei gesunden Milchkühen und ihre Bedeutung für die Milchleistung aufzuzeigen. Die Studie wurde mit 22 gesunden Milchkühen durchgeführt, die in 2 Gruppen unterteilt wurden: Tiere mit geringer und Tiere mit hoher Milchleistung. Die Ergebnisse zeigten, dass die hochleistenden Tiere höhere LOOH-Werte aufwiesen als die Tiere mit niedriger Milchleistung. Diese Zunahme an oxidierbaren Stoffen wird jedoch nicht von einer Mengenzunahme an schützenden Antioxidantien begleitet. Zusätzlich zu den üblichen metabolischen Parametern liefern die LOOH-Werte und der TAS weitere Informationen über den metabolischen Status des Tieres.

Schlüsselwörter: Plasmalipidhydroperoxidwerte, Gesamtantioxidansstatus, Milchkühe

\section{Introduction}

Amongst domestic farm animals the metabolic diseases acquire their greatest importance in dairy cows and pregnant ewes. High yielding dairy cows always verge on abnormal homeostasis and the breeding and feeding of dairy cattle for milk yields is etiologically related to metabolic diseases so common in these animals (ALLISON and LAVEN, 2000). For this reason, metabolic profiles have been used in an attempt to monitor health, reproductive and nutritional status. However, the results and recommendations made by different authors vary widely and are often contradictory. This may be due to many factors like diet, specific requirements for certain nutrients or environmental conditions (HILLMAN, 1997). 
In the last few years, the detection of free radical damage and the protection against it has become very important in the practice of clinical medicine. In fact, it is difficult to open a veterinary journal these days without seeing a paper on free radicals and their role in animal disease. Free radicals are produced continuously during metabolism and their production can multiply as a result of many circumstances, not only pathological ones (ROTH, 2000). Lipid peroxidation is known to be a free radical chain reaction which forms lipid hydroperoxides and secondary products. The latter are highly reactive and have been shown to interact with many biological components such as proteins, aminoacids, amines or DNA (CASTILLO et al., 2001a).

On the other hand, the animal body has a variety of protective antioxidant substances that act as a harmoniously and finely tuned mechanism to neutralize harmful oxidants (MILLER et al., 1993; NEMEC et al., 2000). When the oxidant substances are not effectively and safely removed, oxidative stress may impair health in dairy cows both directly and indirectly (SIES, 1985; MILLER et al., 1993; DAVIES, 2000). Direct effects include peroxidation damage to important lipids and macromolecules. Indirect changes induced by oxidants in cellular membranes and components can modify metabolic pathways, resulting in altered physiology and possibly pathology (CASTILLO et al., 2001a). This fact is important in dairy cows, where lactation imposes great physiological challenges on the homeostatic mechanism of the animal (GOFF and HORST, 1997).

For this reason, we think that independently of traditional metabolic tests, it is important to evaluate the balance between prooxidant and antioxidant substances using two parameters: lipoperoxide production and the total antioxidant status. In this way, we can obtain a deeper knowledge of the metabolic status of the animal. Therefore, this report aims to establish values for plasma lipoperoxides and total antioxidant status, and to determine the relationship with the information given by the determination of traditional metabolic parameters in dairy cows and field conditions. Emphasis is placed on the general health status of the cows to establish a basis for future investigations into the role of free radicals and antioxidant balance in the pathogenesis of veterinary diseases.

\section{Materials and Methods}

\section{Animals}

The study was carried out on 22 healthy multiparous Holstein cows maintained in a commercial dairy farm in Lugo (Galicia, N.W. Spain). These animals were divided into two groups: 10 animals in their sixth month of lactation and with a milk yield of 20 litres per animal and day. The other group was composed of 12 lactating animals, at their peak of lactation, with a mean milk yield of 35 litres per animal and day.

The diet received was composed of grass silage, soybean (44\% C.P.) concentrate (18\%

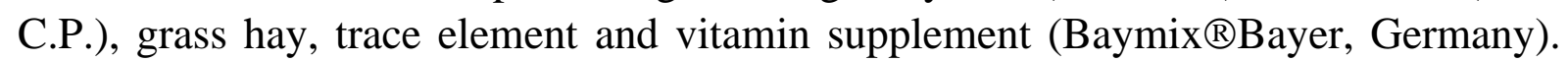
The diet was adjusted to maintain the requirements established for lactation and so, in the high-producing group the administration of concentrate was increased proportionally to milk yield, receiving 5 kilograms more of concentrate than the lowproducing group. The cows were allowed to eat twice a day: in the morning from 8:00 to 11:00 and in the afternoon from 5:00 to 8:00. 
Sample collection and analytical procedures

Blood samples were obtained by jugular venipunction, using Vacutainer ${ }^{\circledR}$ tubes with heparin (for plasma lipid hydroperoxides and total antioxidant status determinations) and without anticoagulant (for serum metabolite analyses). The plasma obtained was kept at $2-8^{\circ} \mathrm{C}$ and assayed within 24 hours. Serum was stored at $-20^{\circ} \mathrm{C}$ until use.

\section{Measurement of plasma lipid hydroperoxides $(\mathrm{LOOH})$}

Concentration of lipid hydroperoxides in plasma was measured by means of a simple direct colorimetric technique based on the oxidation of ferrous ions to ferric ions by hydroperoxides under acidic conditions (NOUROOZ-ZADEH et al., 1994). The ferric ion binds with xylenol orange to form a stable and colored complex which can be measured at $560 \mathrm{~nm}$. To eliminate $\mathrm{H}_{2} \mathrm{O}_{2}$ interference from the lipid hydroperoxide measurement, the sample is pretreated with catalase to descompose the existing $\mathrm{H}_{2} \mathrm{O}_{2}$. To quantify and substract the non-LOOH produced $560 \mathrm{~nm}$ signal, a sample blank is assayed after treatment with tris(2-carboxyethyl)phosphine (TCEP), which reduces lipid hydroperoxides to the corresponding organic alcohols. The difference in absorbance at $560 \mathrm{~nm}$ for samples with and without TCEP is due to the LOOH content.

\section{Measurement of total antioxidant status (TAS) in plasma}

This parameter was measured using the standardised kit of Randox Laboratories Ltd., based on the incubation of ABTS ${ }^{\circ}$ (2,2'-Azino-di-[3-ethylbenzthiazoline sulphonate], Boehringer Mannheim, Germany) with a peroxidase (metamyoglobin) and $\mathrm{H}_{2} \mathrm{O}_{2}$ to produce the radical cation $\mathrm{ABTS}^{+}{ }^{+}$. This has a relatively stable blue-green colour which is measured at $600 \mathrm{~nm}$. For accuracy and reproducibility control, a Randox Total Antioxidant Control was used.

Measurement of metabolic parameters

Serum glucose, triglycerides, cholesterol, urea, total proteins, albumin and alanineaminotransferase activity (ASAT) were measured using standardized techniques supplied by Gernon Laboratories (Clinical Chemistry and Diagnostics, Germany). Serum non-esterified fatty acids (NEFA) were assayed with the standardized technique supplied by Randox Laboratories (U.K.)

\section{Statistical procedure}

The reported values are mean \pm standard error. Statistical evaluation of data was performed by use of one-way analysis of variance. The statistical differences were established taking into account a $\mathrm{p}<0.05$.

\section{Results}

Plasma and serum parameters between groups are reflected in the Table.

By way of summary we must point out the high levels of serum NEFA, triglycerides, urea and albumin, in comparison to basal data published (KANEKO et al., 1997; MOORE, 1997; RADOSTITS et al., 2000), without statistical differences between groups, excepting urea concentrations, although we can observe higher values in the 
high-producing group. The other metabolic parameters, like serum glucose, ASAT, cholesterol and total proteins are within physiological ranges.

The mean values of LOOH and TAS cannot be compared with other studies owing to three factors: i), most of these are performed on sick animals while our study was carried out on animals without clinical signs of illness ii), the mean values, in sick animals, are obtained with different analytical techniques such as malondialdehyde (MDA), 4-hydroxy-2E-nonenal or 13-hydroperoxy linoleic acid determinations (MOORE and ROBERTS, 1998; DIPLOCK, 2000) and iii), many data refer to tissues other than plasma (liver, placental tissues, muscles, cervical mucus...). So, we can only describe our results, and thus we can establish that the cows at their peak of lactation have significantly higher $\mathrm{LOOH}$ levels, while there are no statistical differences between groups in relation to the total antioxidant status.

Table

Mean values ( $\mu \pm$ std. error) of the studied parameters (Durchschnittswerte $(\mu \pm$ Standardabweichung) der untersuchten Parameter)

\begin{tabular}{|c|c|c|c|}
\hline Parameter & Group & $\mu \pm$ std. error & Comparison \\
\hline \multirow[t]{2}{*}{$\mathrm{LOOH}(\mu \mathrm{M})$} & Low-producing cows & $9.87 \pm 2.74$ & 0.022 \\
\hline & High-producing cows & $16.54 \pm 2.72$ & \\
\hline \multirow[t]{2}{*}{ TAS (mmol/l) } & Low-producing cows & $0.324 \pm 0.021$ & N.S. \\
\hline & High-producing cows & $0.377 \pm 0.046$ & \\
\hline \multirow[t]{2}{*}{ Glucose (mg/dl) } & Low-producing cows & $68.20 \pm 1.73$ & N.S \\
\hline & High-producing cows & $65.38 \pm 2.58$ & \\
\hline \multirow[t]{2}{*}{ Cholesterol (mg/dl) } & Low-producing cows & $202.60 \pm 15.92$ & N.S. \\
\hline & High-producing cows & $189.16 \pm 18.78$ & \\
\hline \multirow[t]{2}{*}{ Triglycerides (mg/dl) } & Low-producing cows & $115.76 \pm 13.78$ & N.S. \\
\hline & High-producing cows & $146.41 \pm 19.51$ & \\
\hline \multirow[t]{2}{*}{ NEFA (mmol/l) } & Low-producing cows & $0.425 \pm 0.018$ & N.S. \\
\hline & High-producing cows & $0.598 \pm 0.04$ & \\
\hline \multirow[t]{2}{*}{ Urea (mg/dl) } & Low-producing cows & $34.04 \pm 5.14$ & 0.045 \\
\hline & High-producing cows & $45.10 \pm 4.82$ & \\
\hline \multirow[t]{2}{*}{ ASAT (IU/l) } & Low-producing cows & $99.00 \pm 7.58$ & N.S. \\
\hline & High-producing cows & $112.15 \pm 9.35$ & \\
\hline \multirow[t]{2}{*}{ Albumin (g/dl) } & Low-producing cows & $3.91 \pm 0.09$ & N.S. \\
\hline & High-producing cows & $4.04 \pm 0.16$ & \\
\hline \multirow[t]{2}{*}{ Total protein (g/dl) } & Low-producing cows & $7.37 \pm 0.18$ & N.S. \\
\hline & High-producing cows & $7.17 \pm 0.22$ & \\
\hline
\end{tabular}

\section{Discussion}

The high concentrations of serum triglycerides, NEFA and urea are related to the effect of a high dietary lipid and protein concentration, which is due to the amount of feed based on soybean and concentrate (OPSOMER and De KRUIF, 1995; WATTIAUX and GRUMMER, 2000). Nevertheless, the levels of glucose indicate that the animals have an adequate energy balance (MOORE, 1997) without altering hepatic function, as shown by ASAT activities and cholesterol values, indexes of hepatic 
lipidosis (ONO et al., 1988; MARCOS et al., 1990; ROUSSEL et al., 1997). RADOSTITS et al. (2000) point out that the feed intake of dairy cows on commercial farms is commonly incorrect in relation to concentrate feeding, and errors of more than $50 \%$ in feed intake are sometimes found. In our study, this criterion can be applied to both groups, especially the high-producing cows that receive more quantities of concentrate, which explains the higher levels reached in the above mentioned blood metabolites. HILLMAN (1997) pointed out that theoretical nutritional recommendations are adequate for lactation under conditions of a balanced diet, typical environment and management, but they are often different on many occasions from field conditions, like our case.

Independently of nutrition, it is well known that lactation itself imposes specific physiological demands that modify the homeostatic mechanism of the animal owing to milk synthesis, and these demands run parallel to milk yield (GOFF and HORST, 1997; HARTMAN et al., 1998). During this stage the consumption of $\mathrm{O}_{2}$ increases markedly with a greater generation of reactive oxygen metabolites and the consumption of antioxidants (KOLB and SEEHAWER, 2000; ROTH, 2000). This fact itself can justify the differences found in $\mathrm{LOOH}$ values between groups, although we cannot exclude the influence of diet at this moment on this parameter. In ruminant nutrition, this kind of diet, rich in essential fatty acids, has adverse effects like the increased conversion of polyunsaturated fatty acids, derived from essential fatty acids, to lipid peroxides (HUSVÉTH et al., 2000; CASTILLO et al., 2001b).

But normally the body is protected by a wide range of antioxidant systems that neutralise harmful oxidants (NEMEC et al., 2000). Our results reveal that the increase in $\mathrm{LOOH}$ production is not parallel to an increase in TAS levels. This means that the metabolism of these cows produces peroxides faster than their antioxidant system can cope with: this group of animals would be predisposed to an oxidative stress status, a disturbance in the prooxidant/antioxidant systems in favour of the former (SIES, 1985; DAVIES, 2000) with serious negative effects on animal health.

As we can see, $\mathrm{LOOH}$ and TAS values give us greater information than the traditional metabolic parameters used alone, especially glucose or NEFA concentrations, whose values can be modified by many factors, such as breed or individual influences, hormonal status or nutritional management (OPSOMER and De KRUIF, 1995; RADOSTITS et al., 2000), although we wish to point out that LOOH and TAS measurements should be considered a complementary evaluation, and that they cannot exclude the information given by the former parameters.

Taking into account that an oxidative stress status can result from increased exposure to oxidants or decreased protection against oxidants or even both problems occurring simultaneously (DAVIES, 2000), and on the basis of our results, we point out that the future nutritional recommendations for dairy animals should not be based only on energy and protein requirements but on antioxidant needs, too, in order to promote the health and well-being, and reduce the risk of disease (BRZEZINSKASLEBODZINSKA et al., 1994; DIPLOCK, 2000). In fact, the currently recommended intake of vitamins and minerals for these animals is based on the prevention of certain diseases, such as retained placenta, udder edema or mastitis without considering the balance between prooxidant and antioxidant substances in the organism (MILLER et al., 1993; BRZEZINSKA-SLEBODZINSKA et al., 1994; WEISS, 1998; ALLISON and LAVEN, 2000; KOLB and SEEHAWER, 2000). Furthermore, the majority of 
data regarding this matter comes from North America, where cows encounter different levels of oxidative stress from cows in the E.U. (ALLISON and LAVEN, 2000). We think that there is a need for more research into the practical knowledge of antioxidant supplement in healthy animals and field conditions.

\section{Conclusions}

The employment of LOOH and TAS values is a complementary and necessary tool in a greater evaluation of the metabolic status. Nevertheless they cannot exclude the information given by the traditional metabolic parameters.

It is necessary to establish baseline values, in healthy animals, in relation to the balance between prooxidant and antioxidant substances, because the future nutritional recommendations for dairy animals will not be based only on energy and protein requirements but in antioxidant needs too.

\section{References}

ALLISON, R.D.; LAVEN, R.A.:

Effect of vitamin E supplementation on the health and fertility of dairy cows: a review. Vet. Rec. 147 (2000), 703-708

BRZEZINSKA-SLEBODZINSKA, E.; MILLER, J.K.; QUIGLEY, J.D.; MOORE, J.R.; MADSEN, F.C.:

Antioxidant status of dairy cows supplemented prepartum with vitamin E and selenium. J. Dairy Sci. 77 (1994), 3087-3095

CASTILLO, C.; BENEDITO, J. L.; LÓPEZ ALONSO, M.; MIRANDA, M.; HERNÁNDEZ, J.: Importancia del estrés oxidativo en ganado vacuno: en relación con el estado fisiológico (preñez y parto) y la nutrición. Arch. Med. Vet. 33 (2001a), 5-20

CASTILLO, C.; HERNÁNDEZ, J.; LÓPEZ ALONSO, M.; MIRANDA, M.; BENEDITO, J. L.:

A different point of view of glutathione peroxidase: its relationship to the metabolic changes associated with nutritional management in Assaf ovine breed. Arch. Anim. Breed., Dummerstorf 44 (2001b), 305312

DAVIES, K.J.A.:

Oxidative stress, antioxidant defences, and damage removal, repair and replacement systems. Life $\mathbf{5 0}$ (2000), 270-289

DIPLOCK, A.T.:

Introduction: markers of oxidative damage and antioxidant modulation. Free Rad. Res. 33 (2000), Suppl: S21-S26

GOFF, J.P.; HORST, R.L.:

Physiological changes at parturition and their relationship to metabolic disorders. J. Dairy Sci. 80 (1997), 1260-1268

HARTMAN, P.E.; SHERRIFF J.L.; MITOULAS L.R.:

Homeostatic mechanisms that regulate lactation during energetic stress. Am. Soc. Nutr. Sci. Suppl. (1998), 394-399

HILLMAN, D.:

Dietary nutrient allowances for dairy cattle. Feedstuffs (1997), 56-67

HUSVÉTH, F.; MANILLA, H.A.; GAÁL, T.; VAJDOVICH, P.; BALOGH, N.; WÁGNER, L.; LÓTH, I.; NÉMETH, K.:

Effects of saturated and unsaturated fats with vitamin E supplementation on the antioxidant status of broiler chicken tissues. Acta Vet. Hung. 48 (2000), 69-79

KANEKO, J.J.; HARVEY, J.W.; BRUSS, M.L.:

Appendixes. In: KANEKO, J.J.; HARVEY, J.W.; BRUSS, M.L. (Editors), Clinical Biochemistry of Domestic Animals. Academic Press, San Diego, USA (1997), 885-905

KOLB, E.; SEEHAWER, J.:

Effect of stress on cortisol secretion and vitamin metabolism in cattle. Praktischer Tierarzt 81 (2000), 1037-1046

MARCOS, E.; MAZUR, A.; CARDOT, P.; RAYSSIGUIER, Y.:

The effect of pregnancy and lactation on serum lipid and apolipoprotein B and A-I levels in dairy cows. J. Anim. Physiol. Anim. Nutr. 64 (1990), 133-138 
MILLER, J. K.; BRZEZINSKA-SLEBODZINSKA, E.; MADSEN F. C.:

MOORE, F.:

Oxidative stress, antioxidants and animal function. J. Dairy Sci. 76 (1993), 2812-2823

Serum Chemistry profiles in dairy cows: A herd management tool?. Vet. Med. (1997), 986-991

MOORE, K.; ROBERTS, L. J.: Measurement of lipid peroxidation. Free Rad. Res. 28 (1998), 659-671

NEMEC, A.; DROBNIC-KOSOROK, M.; SKITEK, M.; PAVLICA, Z.; GALAC, S.; BUTINAR, J.: Total antioxidant capacity (TAC) values and their correlation with individual antioxidant in serum of healthy beagles. Acta Vet. Brno 4 (2000), 297-303

NOUROOZ-ZADEH, J.; TAJADDINI-SARMADI, J.; WOLFF, S. P.:

Measurement of plasma hydroperoxide concentrations by the ferrous oxidation-xylenol orange assay in conjunction with triphenylphosphine. Anal. Biochem. 220/2 (1994), 403-409

ONO, E.; ABE, T.; TAGUCHI, K.; SATO, T.; NAIKI, M.:

Fatty acids analysis of lipid components of livers from dairy cows with high levels of serum free fatty acids. Jpn. J. Vet. Sci. 50 (1988), 900-907

OPSOMER, G.; De KRUIF, A.:

The influence of some environmental factors on the concentration of important energy parameters in the blood of high producing dairy cows. Proc. of the IX ${ }^{\text {th }}$ International Conference on Production Diseases in Farm Animals. Berlin (1995), 59

RADOSTITS, O.M.; GAY, C.C.; BLOOD, D.C.; HINCHCLIFF, K.W.:

ROTH, E.: Veterinary Medicine. W.B. Saunders, Philadelphia, USA (2000)

Oxygen free radicals and their clinical implications. Acta Chir. Hung. 36 (2000), 302-305

ROUSSEL, A.J.; WHITNEY, M.S.; COLE, D.J.: SIES, H.: Interpreting a bovine serum chemistry profile: Part I. Vet. Med. (1997), 553-566

Oxidative stress: introductory remarks. In: SIES, H. (Editor) Oxidative stress. Academic Press, London, UK (1985), 1-8

WATTIAUX, M.A.; GRUMMER, R.R..:

Lipid metabolism in dairy cows. Web site of Babcock Institute for International Dairy Research and Development. University of Wisconsin, USA (2000)

WEISS, W.P.:

Requirements of fat-soluble vitamins for dairy cows: a review. J. Dairy Sci. 81 (1998), 2493-2501

Received: 2002-09-20

Accepted: 2003-05-05

Author's address

CRISTINA CASTILLO*, DVM, MsC, PhD; JOAQUIN HERNANDEZ, DVM, MsC, PhD, MARTA LOPEZ-ALONSO, DVM, MsC, PhD, MARTA MIRANDA, DVM, MsC, PhD, JOSE LUIS BENEDITO, DVM, MsC, PhD, Prof.

Departamento de Patología Animal, Facultad de Veterinaria,

Universidad de Santiago de Compostela, Campus Universitario s/n,

27002-LUGO, España

Spanien

*Corresponding author: E-Mail: ccasti@correo.usc.es 